American Journal of Animal and Veterinary Sciences 5 (2): 146-150, 2010

ISSN 1557-4555

(C) 2010 Science Publications

\title{
Isolation and Identification of Epiphytic Lactic Acid Bacteria from Guinea Grass (Panicum maximum)
}

\author{
${ }^{1}$ M. Pasebani, ${ }^{1}$ H. Yaakub, ${ }^{2}$ K. Sijam and ${ }^{1}$ A.R. Alimon \\ ${ }^{1}$ Department of Animal Science, Faculty of Agriculture, \\ ${ }^{2}$ Department of Plant Protection, Faculty of Agriculture, \\ University Putra Malaysia, 43400 UPM Serdang, Malaysia
}

\begin{abstract}
Problem statement: Bacteria can perform a variety of beneficial functions, for example many lactic acid bacteria are responsible for fermentation of silage in the process of forage conservation. In the making of silage, epiphytic lactic acid bacteria are usually insufficient in numbers to promote efficient lactate fermentation. This study was conducted to identify the predominant indigenous bacteria, with emphasis on lactic acid bacteria, from Guinea grass (Panicum maximum). Approach: Two different condition of growth using nutrient and MRS agar were prepared for isolation of the bacteria. In total, 18 purified isolates were identified by BIOLOG identification system which comprised of 9 bacterial species. Standard plate count in the both conditions was considered. Results: Three bacterial species based on the first condition of growth were identified which were belonging to Flavimonas oryzihabitans, Enerobacter cloacae, Sphingomonas paucimobilis B. Lactic acid bacteria based on the second condition of growth were belonging to Weissella confusa, Weissella paramesenteroides, Leuconostoc mesenteroides ssp. dextranicum, Lactococcus lactis ssp. hordniae. Result of plate count showed that $8.3 \times 10^{3}$ CFU lactic acid bacteria are available per gram of fresh guinea grass. Conclusion: Three heterofermentative and one homo-fermentative lactic acid bacteria were identified which would be suggested to use as bacterial inoculants because of the insufficient amount of epiphytic lactic acid bacteria and the availability of pathogenic bacteria in the grass.
\end{abstract}

Key words: Isolation, identification, predominant bacteria, guinea grass

\section{INTRODUCTION}

The natural feeds for ruminants are generally grasses, forbs and forages. Grassland either native or improved, are predominantly used in ruminant production systems throughout the world. Guinea grass (Panicum maximum) is one of the grass species of tribe Paniceae under the Gramineae family (Mcdonald et al., 2002). This grass is a native of Africa which has warm climate with over $900 \mathrm{~mm}$ rainfall (Barnes et al., 2007).

Lactic acid bacteria are involved in the fermentation of silage and lower the $\mathrm{pH}$ of the grass to about 4 (Stiles, 1996) whereas other unwanted bacteria such as Clostridia or Enterobacteria increase the $\mathrm{pH}$ value, with the acetic acid and butyric acid in silage and hence producing ammonia-N, amines, keto acids and fatty acids and decreasing the nutritional value (McDonald, 1981). Bacterial inoculants can speed the process of lactic acid fermentation and improve preservation of forage because epiphytic LAB is often insufficient in numbers for efficient lactate fermentation (McDonald, 1981). For example, Bureenok showed et al. (2005) that increasing the volume of fermented juice of epiphytic lactic acid bacteria as inoculants resulted in increased production of high fermentative quality in guinea grass silage.

\section{MATERIALS AND METHODS}

Guinea grass (Panicum maximum var. trichoglume) was planted at the University Putra Malaysia's farm in a size of approximately one hectare. Samples of whole plant at about 5 weeks re-growth were taken randomly (Mislevy, 1985) and cut into pieces of about $1 \mathrm{~cm}$ by using sterile scissors. Isolation of both predominant indigenous bacteria and epiphytic lactic acid bacteria was carried out in two different methods. For predominant indigenous bacteria, $10 \mathrm{~g}$ sample of the fresh grass was homogenized for $2 \mathrm{~min}$ in $90 \mathrm{~mL}$ sterile peptone water $\left(25.5 \mathrm{~g} \mathrm{~L}^{-1}\right)$, using a vortex. Ten-fold serial dilution $\left(10^{-1}\right.$ till $\left.10^{-5}\right)$ was then carried out in

Corresponding Author: H. Yaakub, Department of Animal Science, Faculty of Agriculture, University Putra Malaysia, 43400 UPM Serdang, Selangor, Malaysia 
triplicates and $100 \mu \mathrm{L}$ of last dilution was placed on nutrient agar $\left(20 \mathrm{~g} \mathrm{~L}^{-1}\right)$ (Merck, Germany) and incubated at $35^{\circ} \mathrm{C}$ under aerobic condition until colonies were visible. For epiphytic lactic acid bacteria, $10 \mathrm{~g}$ sample of the grass was homogenized for $2 \mathrm{~min}$ in $90 \mathrm{~mL}$ sterile MRS broth (52.5 $\mathrm{g} \mathrm{L}^{-1}$ ) (Merck, Germany), using a vortex. 10-fold serial dilution $\left(10^{-1}\right.$ till $10^{-3}$ ) was then carried out and kept in an incubator at $30^{\circ} \mathrm{C}$ for $3 \mathrm{~h} .100 \mathrm{~mL}$ of last dilution was then placed on MRS agar (68.2 $\mathrm{g} \mathrm{L}^{-1}$ ) (Merck, Germany) in triplicates and kept in anaerobic condition using anaerobic jar. Finally, they were incubated at $30^{\circ} \mathrm{C}$ until colonies were visible. Standard plate count in both methods was done in triplicates. morphology were chosen by using a bright-field microscope (Nikon, E200. USA). Then, they were subcultured for two or three times to get purified bacteria. The gram staining test using the four reagents (crystal Secondary staining test, $\mathrm{KOH}$ test, was considered as a confirmation for gram staining. Later, Oxidize test were done for the gram negative isolates to determine whether they are enteric or non enteric microbe.

Identification of the isolates was carried out by using BIOLOG identification system. Fresh purified Negative/Positive (GN/GP) inoculation fluid for indigenous isolates and Anaerobic (AN) inoculation fluid for the isolates of lactic acid bacteria by using sterile cotton swap. Turbidity of the inoculants was adjusted to $63 \%$ for enteric bacteria and lactic acid bacteria isolates and $52 \%$ for non enteric bacteria by using turbidity meter. Isolation of gram negative enteric bacteria required the addition of thioglycolate (3 drops) as an anti capsulate agent which reduced production of
Single colonies from both methods based on violet, acetone, safranin and iodine) were conducted. culture of the isolates were inoculated into Gram

bacterial capsules and hence, strains gave more consistent patterns. Following this, gram negative and anaerobic micro plates were prepared and kept in aerobic and anaerobic condition respectively, for 424 h. Finally, reading of these micro plates were carried out using BIOLOG reader (Micro log system $^{\mathrm{TM}}$, Release 4.0).

\section{RESULTS}

A total of 18 isolates were obtained from the two methods of isolation. Results of gram staining test, $\mathrm{KOH}$ test and oxidize test (for gram negative bacteria) are shown in Table 1. Indigenous isolates were gram negative and oxidize positive except of isolate number 1-1 which was gram negative and oxidize negative.

Table 1: Result of gram staining test, $\mathrm{KOH}$ test and oxidize test and morphology of all the isolates

\begin{tabular}{lllll}
\multicolumn{5}{c}{ morphology of all the isolates } \\
Isolates & $\begin{array}{l}\text { Gram staining } \\
\text { test }\end{array}$ & $\begin{array}{l}\text { KOH } \\
\text { test }\end{array}$ & $\begin{array}{l}\text { Oxidize } \\
\text { test }\end{array}$ & Shape \\
\hline$* 1-1$ & - & - & - & Rod \\
$1-2$ & - & - & + & Rod \\
$1-3$ & - & - & + & Rod \\
$1-4$ & - & - & + & Rod \\
$1-5$ & - & - & + & Rod \\
$1-6$ & - & - & + & Rod \\
$1-7$ & - & - & + & Rod \\
$1-8$ & - & - & + & Rod \\
$1-9$ & - & - & + & Rod \\
$2-1$ & + & + & $* * n$ & Coccid \\
$2-2$ & + & + & $n$ & Coccid \\
$2-3$ & + & + & $n$ & Coccid \\
$2-4$ & + & + & $n$ & Coccid \\
$2-5$ & + & + & $n$ & Coccid \\
$2-6$ & + & + & $n$ & Rod \\
$2-7$ & + & + & $n$ & Coccid \\
$2-8$ & + & + & $n$ & Coccid \\
$2-9$ & + & + & $n$ & Coccid \\
\hline$*$ Batch number of isolation and number of isolate in each batch; $*$ Null
\end{tabular}

Table 2: Identification details of the isolates

\begin{tabular}{lllccc}
\hline Isolates & Level of ID & Name & Probability $(\%)$ & Similarity & Distance between two species \\
\hline $1-1$ & Species & Flavimonas oryzihabitans & 100 & 0.707 & $7.64-4.45=3.19$ \\
$1-2$ & Species & Enerobacter cloacae & 99 & 0.578 & $8.20-6.50=1.70$ \\
$1-3$ & Species & Sphingomonas paucimobilis B. & 100 & 0.566 & $11.25-6.80=4.45$ \\
$1-4$ & Species & Sphingomonas paucimobilis B. & 100 & 0.504 & $10.90-7.92=2.98$ \\
$1-5$ & Species & Sphingomonas paucimobilis B. & 100 & 0.551 & $10.14-7.07=3.07$ \\
$1-6$ & Species & Sphingomonas paucimobilis B. & 100 & 0.592 & $10.33-6.36=3.97$ \\
$1-7$ & Species & Sphingomonas paucimobilis B. & 100 & 0.549 & $10.17-7.11=3.06$ \\
$1-8$ & Genus & Sphingomonas paucimobilis B. & --- & 0.317 & $8.08-7.90=0.18$ \\
$1-9$ & Species & Sphingomonas paucimobilis B. & 100 & 0.551 & $11.14-7.07=4.07$ \\
$2-1$ & Species & Peptostreptococcus hydrogenalis & 100 & 0.720 & $7.08-4.22=2.86$ \\
$2-2$ & Species & Weissella confusa & 100 & 0.580 & $10.51-6.57=3.94$ \\
$2-3$ & Species & Weissella paramesenteroides & 100 & 0.550 & $10.75-7.14=3.61$ \\
$2-4$ & Species & Leuconostoc mesenteroides ssp. dextranicum & 97 & 0.640 & $6.50-5.21=1.29$ \\
$2-5$ & Species & Leuconostoc mesenteroides ssp. dextranicum & 100 & 0.570 & $9.27-6.71=2.56$ \\
$2-6$ & Species & Clostridium innocuum & 100 & 0.600 & $8.46-6.22=2.24$ \\
$2-7$ & Species & Lactococcus lactis ssp. hordniae & 97 & 0.670 & $6.24-4.76=1.48$ \\
$2-8$ & Species & Weissella paramesenteroides & 97 & 0.520 & $8.69-7.34=1.35$ \\
$2-9$ & Species & Peptostreptococcus hydrogenalis & 100 & 0.600 & $8.95-6.30=2.65$ \\
\hline
\end{tabular}


Furthermore, all the identified bacteria from the isolation method of lactic acid bacteria were gram positive. With regards to the morphology, all isolates from the first batch and second batch were in rod shaped and coccid, respectively, with the exception of isolate number 2-6 which was rod.

Standard plate count of bacteria for the fresh grass represented an amount of bacteria equal to $2.65 \times 10^{5} \mathrm{CFU} \mathrm{g}^{-1}$. Standard plate count of lactic acid bacteria for the fresh grass by considering $3 \mathrm{~h}$ activation time in MRS broth and at the temperature $30^{\circ} \mathrm{C}$ before serial dilution showed that the amount of these bacteria is equal to $8.3 \times 10^{3} \mathrm{CFU} \mathrm{g}^{-1}$.

The 18 purified isolates were identified as 9 bacterial species, belonging to Flavimonas oryzihabitans, Enterobacter cloacae, Sphingomonas paucimobilis B. Weissella confusa, Weissella paramesenteroides, Leuconostoc mesenteroides ssp. dextranicum and Lactococcus lactis ssp. hordniae. The Peptostreptococcus hydrogenalis and Clostridium innocиum, have been isolated when general condition of growth was provided. Identification details of all isolates presented in Table 2.

\section{DISCUSSION}

The probability and similarity index must be considered in identification of bacteria by BIOLOG identification system. According to manufacturer's user guide of microlog system (1999), result of the identification is reliable when the similarity is 0.5 and above. Distance is a character which shows how far are between the species of identified bacteria and nearest species and it must be more than 2. According to Table 2, result of all the isolates are trustable except of number 2 and 8 from first batch and number 4,7 and 8 from second batch. Although the distance in isolate number 1-2 and 2-7 is just under 2, but the result has been accepted because of very good probability and similarity. The bacterial species given as isolate number $1-8,2-4$ and 2-8 are exactly similar to $1-3,2-5$ and 2-3 respectively and hence, their result were accepted. Several reasons such as contamination can affect the bacterial culture to obtain a wrong or inaccurate result.

Flavimonas oryzihabitans was isolated from different brands of mineral water in Australia (Jayasekara et al., 1998). It also has been isolated from water, soil and damp environments such as rice paddies and sink drains (Dussart et al., 2003). Flavimonas oryzihabitans is a yellow pigmented, gram-negative, Oxidize-negative, non fermenting bacillus. This bacterium is an uncommon pathogen which can cause opportunistic infections (Dussart et al., 2003).
Enterobacter cloacae previously has been isolated and identified from soil as the cadmium resistant Bacteria (Hu et al., 2007). Cadmium (Cd) is a popular heavy metal with the most toxic pollutants of the surface soil layer (Tang et al., 2006). Cadmium can be found in the roots of plants which affect the nutrient uptake and homeostasis (Di Toppi and Gabrielli, 1999) and then, animals and humans consume $\mathrm{Cd}$ in their diet that can cause diseases (McGrath, 1994).

Using Microorganisms are effective and economical for Bio-sorption properties of cadmium (Esposito et al., 2001). Growth of Sphingomonas paucimobilis is when cadmium concentration is more than $200 \mathrm{mg} \mathrm{L}^{-1}$ and will be inhibited with less than this amount. Living cells of Sphingomonas paucimobilis are more able to remove cadmium in compare to nonliving cells. The bacterial biomass can affect the initial $\mathrm{pH}$ of solution by the mechanism of cadmium Bio-sorption (Tangaromsuk et al., 2002).

Peptostreptococcus hydrogenalis sp. previously isolated from human feces and vaginal discharge which is anaerobic cocci (Ezaki et al., 1990). Clostridium innocuum which was isolated as the normal human intestinal microflora identifies as Glucoseureide (GU) splitting bacteria (Mohr et al., 1999). These two bacteria were died after sub culturing and hence considered as contamination which had been grown by providing semi condition of growth.

Weissella strains have been isolated from a variety of sources. Weissella paramesenteroides (formerly Leuconostoc paramesenteroides), plays an important role in the first phase of silage fermentation (Dellaglio and Torriani, 1986). Weisella confusa has been traced in sugar cane, carrot juice and occasionally in raw milk and sewage (Hammes and Vogel, 1995).

Leuconostoc species are commercially used for the production of glucans (Korakli and Vogel, 2006). Isolation of Leuconostoc mesenteroides subsp. dextranicum is very popular in starter cultures used in dairy industry (Cogan and Jordan, 1994).

Lactococcus lactis species are common in the production of dairy products. Lactococcus Lactis comprises the three subspecies Lactococcus lactis ssp. lactis, Lactococcus lactis ssp. cremoris and Lactococcus lactis ssp. Hordniae (Bolotin et al., 2001).

Lactic acid bacteria can be divided into two categories based on their pathway in carbohydrate metabolism. The homo-fermentative category comprises of Lactocococcus, Pediococcus, Enterococcus, Streptococcus and some lactobacilli. The hetero-fermentative category includes of Leuconostoc, Weissella and some lactobacilli (Ross et al., 2002). 


\section{CONCLUSION}

It would be suggested to feed this grass to ruminants in form of silage since the growth of pathogenic bacteria such as Flavimonas oryzihabitans or Enterobacter cloacae will be inhibited in $\mathrm{pH}$ range of 4. All together four lactic acid bacteria were isolated from fresh guinea grass which three of them including Weissella paramesenteroides, Weisella confusa and Leuconostoc mesenteroides subsp. dextranicum are hetero-fermentative and one of them, Lactococcus lactis ssp. Hordniae, is homofermentative. Bacterial Inoculants suggested to be used in ensilage of guinea grass since the numbers of naturally occurring lactic acid bacteria are very low.

\section{ACKNOWLEGEMENT}

This study was supported by Research University Grant Scheme (RUGS), University Putra Malaysia.

\section{REFERENCES}

Barnes, R.F., J.C. Nelson, K.J. Moore and M. Collin 2007. Forages: The Science of Grassland Agriculture. 6th Edn., Wiley, ISBN: 13: 9780813802329, pp: 791.

Bolotin, A., P. Wincker, S. Mauger, O. Jaillon and K. Malarme et al., 2001. The complete genome sequence of the lactic acid bacterium Lactococcus lactis ssp. lactis IL1403. Genome Res., 11: 731-753. PMID: 11337471

Bureenok, S., T. Namihira, Y. Kawamoto and T. Nakada, 2005. Additive effects of fermented juice of epiphytic lactic acid bacteria on the fermentative quality of guineagrass (Panicum maximum Jacq.) silage. Grassland Sci., 51: 243-248. DOI: 10.1111/j.1744-697X.2005.00032.x

Cogan, T.M. and K.N. Jordan, 1994. Metabolism of leuconostoc bacteria. J. Dairy Sci., 77: 2704-2717. DOI: 10.3168/jds.S0022-0302(94)77213-1

Dellaglio, F. and S. Torriani, 1986. DNA \pm DNA homology, physiological characteristics and distribution of lactic acid bacteria from maize silage. J. Applied Bacteriol., 60: 83-92. DOI: 10.1111/j.1365-2672.1986.tb03363.x

Di Toppi, S.L. and R. Gabrielli, 1999. Response to cadmium in higher plants. Environ. Exp. Bot., 41: 105-130. DOI: 10.1016/S0098-8472(98)00058-6

Dussart, L., J.P. Dupont, I. Zimmerlin, M. Lacroix and J.M. Saiter et al., 2003. Occurrence of sessile Pseudomonas oryzihabitans from a karstified chalk aquifer. Water Res., 37: 1593-600. DOI: 10.1016/S0043-1354(02)00555-9
Esposito, A., F. Pagnanelli, A. Lodi, C. Solisio and F. Veglio, 2001. Biosorption of heavy metals by Sphaerotilus natans: An equilibrium study at different $\mathrm{pH}$ and biomass concentrations. Hydrometallurgy, 60: 129-141. DOI: 10.1016/S0304-386X(00)00195-X

Ezaki, T., S. Liu, Y. Hashimoto and E. Yabuuchi, 1990. Peptostreptococcus hydrogenalis sp. nov. from human fecal and vaginal flora. Int. J. Syst. Bacteriol., 40: 305-306. http://ijs.sgmjournals.org/cgi/content/abstract/40/3/ 305

Hammes, W.P. and R.F. Vogel, 1995. The Genus Lactobacillus. In: The Genera of Lactic Acid Bacteria, Holzapfel, W.H.N. and B.J.B. Wood (Eds.). Blackie Academic and Professional, Glasgow, ISBN: 10: 075140215X, pp: 19-54.

$\mathrm{Hu}$, Q., M. Dou, H. Qi, X. Xie, G. Zhuang and M. Yang, 2007. Detection, isolation and identification of cadmium-resistant bacteria based on PCR-DGGE. J. Environ. Sci., 19: 1114-1119. DOI: 10.1016/S1001-0742(07)60181-8

Jayasekara, N.Y., G.M. Heard, J.M. Cox and G.H. Fleet, 1998. Populations of pseudomonads and related bacteria associated with bottled noncarbonated mineral water. Food Microbiol., 15: 167-176. DOI: 10.1006/fmic. 1997.0146

Korakli, M. and R.F. Vogel, 2006. Structure/function relationship of homopolysaccharide producing glycansucrases and therapeutic potential of their synthesized glycans. Applied Microbiol. Biotechnol., 71: 790-803. DOI: 10.1007/s00253006-0469-4

McDonald, P., R.A. Edwards, J.F.D. Greenhalgh and C.A. Morgan, 2002. Animal Nutrition. 6th Edn., Pearson Education Limited, UK., ISBN: 13: 9780582419063, pp: 708.

McDonald, P., 1981. The Biochemistry of Silage. 1st Edn., John Wiley and Sons Ltd., Marlow, UK., ISBN: 13: 978-0471279655, pp: 226.

McGrath, S.P., 1994. Effects of Heavy Metals from Sewage Sludge on Soil Microbes in Agricultural Ecosystems. In: Toxic Metals in Soil-Plant Systems, Ross, S.M. (Ed.). Wiley, New York, ISBN: 0-471-94278-0, pp: 247-273.

Mislevy, P., 1985. Forages for Grazing System in Warm Climates. In: Nutrition of Grazing Ruminants in Warm Climates, McDowell, L.R. (Ed.). Academic Press, Inc., USA., ISBN: 13: 9780124833708, pp: 84-86.

Mohr, C., W.E. Heine and K.D. Wutzke, 1999. Clostridium innocuum: A glucoseureide-splitting inhabitant of the human intestinal tract. Biochim. Biophys. Acta, 1472: 550-554. DOI: 10.1016/S0304-4165(99)00162-2 
Ross, P.R., S. Morgan and C. Hill, 2002. Preservation and fermentation: past, present and future. Int. J. Food Microbiol., 79: 3-16.

Stiles, M.E., 1996. Biopreservation by lactic acid bacteria. Antonie van Leeuwenhoek, 70: 331-345. DOI: 10.1007/BF00395940

Tang, X., Y. Zhu, Y. Cui, J. Duan and L. Tang, 2006. The effect of ageing on the bioaccessibility and fractionation of cadmium in some typical soils of China. Environ. Int., 32: 682-689. DOI: 10.1016/j.envint.2006.03.003
Tangaromsuk, J., P. Pokethitiyook, M. Kruatrachue and E.S. Upatham, 2002. Cadmium biosorption by Sphingomonas paucimobilis biomass. Bioresour. Technol., 85: 103-105. DOI: 10.1016/S09608524(02)00066-4 